\title{
MOOC DEVELOPMENT ON MULTIMEDIA SYSTEMS AND APPLICATIONS COURSE
}

\author{
Murizah Kassim ${ }^{1}$, Hashimah Hashim, Shahrani Shahbudin \\ ${ }^{1}$ Dr. Faculty of Electrical Engineering, Universiti Teknologi MARA, 40450 UiTM Shah Alam, \\ Selangor, Malaysia, murizah@salam.uitm.edu.my
}

\begin{abstract}
Massive Open Online Course (MOOC) is one of an e-learning platform to cater Education 4.0 and Industry 4.0 today. It is identified that MOOC on Multimedia Systems and Applications Course (MSAC) yet to be developed on Open Learning platform. Thus, this research presents a design of MSAC MOOC to provide students with essential knowledge on multimedia systems and applications based on interactive teaching and learning. Students can apply the acquired knowledge in designing multimedia systems and applications such as text, graphics images, audio, video, animation which can be presented online on MOOC. The designed MOOC is different to attracts everybody in the world to participate online no matters which academic background they have. The MOOC course started with a promo video, introductory video, course synopsis, course learning outcome, durations and course plan for 14 weeks. It is also designed with badges and certificates to excellent students who finish the course and able to gain understanding with interactive and active students on the MOOC. Theoretically, eleven topics are covered throughout the MOOC that consists of learning outcome for each topic. Content in text, images, animation and video is designed in subtopic. Practically three activities in each topic are designed with assessment on quizzes and interactive online questions. Educational hyperlink is supported on the MOOC for interactive knowledge based module, video on YouTube and Multimedia channel forum related to the course. Online discussion with students and submitted online short reports is applied to show their understanding of Intellectual Property Rights concept in designing multimedia system and applications. The designed MOOC then is analyzed and result based on student's participations, origins, assessment and feedback from the students is presented. Research is significant in identifying students' completion of the course understanding applied tools. The MOOC course is significant for today's teaching and learning strategy that need to be ready align with new technologies and development.
\end{abstract}

Keywords: Massive open online course (MOOC), e-learning, blended learning, multimedia systems, multimedia applications, course outcome, program outcome.

\section{INTRODUCTION}

Teaching and learning today has become innovative that need to be implemented or adapt to latest technology in communication, its environment and technology gadgets. Massive Open Online Course (MOOC) has become the new platform for certain courses to run that applied some good method and implemented techniques in accessing course on MOOCS. Some projects on development on MOOCs have developed and strengthen an open network for cooperation on open education such as MOOCs. Among the objectives are to determine the opportunities and characteristics for cooperation on MOOCs and to further 
develop these characteristics based on values like openness, equity, quality and diversity. Others are to explicate and develop the didactic and pedagogic models for MOOCs on a scale and to develop the conditions for shared educational services in offering and monitoring MOOCs. An article has reviewed the entrepreneurship education literature to expose the need for engaging teaching methods. Methods of teaching and learning entrepreneurship are concerned that stated that the definition of entrepreneurship education researchers in the various viewpoints of previous researchers, followed by teaching and learning methods are often used by lecturers in teaching entrepreneurship to students (Wahid, Ibrahim, \& Hashim, 2017). This article also examines innovation entrepreneurship teaching and learning methods based on empirical findings from previous research studies but it does not concentrate on teaching on MOOC. The used of MOOCs also presents how students are able to learn by themselves using the latest technology platform today such as web and mobile applications. One research has presented how Self-learning website development through online internet knowledge among engineering students which analysed that today's people are align and updated according to technologies trend (Kassim, Kamal, Sani, \& Johari, 2015). Used of online material implemented in Cisco academy platform also has presented that e-learning activities would help engineering students to develop technical skills levels with a good assessment through online materials (Ab Rahman, Ahmad, Kassim, Ku Haroswati, \& Ku Yahaya, 2009), (Rahman, Zan, Abidin, Kassim, \& Yahaya, 2010).

Since Massive Open Online Courses (MOOCs) started to become part of the scene of Higher Education $(\mathrm{HE})$, many institutions have joined the race of MOOC creation. It is discussed that producing MOOCs has shown to be a cumbersome and expensive activity for HE institutions. Thus, many universities have started to explore and experiment with hybrid initiatives in which locally produced and third-party MOOCs are reused and integrated into traditional courses. Most of the hybrid initiatives described in the literature so far focus on flipped classroom experiences (Arnott \& Planey, 2017), although there are some other possibilities for integrating MOOCs in the curriculum. Some project using MOOCs approach has been done in few developing countries (Murugesan, Nobes, \& Wild, 2017). Moreover, few studies have reported on the institutional support required for implementing hybrid initiatives, and their benefits from a curriculum perspective. In order to shed some light on the opportunities that arise from the reuse of MOOCs, a research presents $\mathrm{H}-\mathrm{MOOC}$, a framework that describes hybrid $\mathrm{MOOC}$ which is based initiatives as a continuum of two factors which is first, the institutional support to reuse an existing MOOC, and secondly curricular content alignment between the MOOC and the program or called hybridized course. This research presents that $\mathrm{H}$ MOOC proposes indicators to measure the impact of these initiatives at both educational and institutional levels. Examples of actual hybrid initiatives and a set of guiding questions are presented to show how to apply the H-MOOC framework in different contexts (Pérez-Sanagustín, Hilliger, Alario-Hoyos, Kloos, \& Rayyan, 2017). A different aspect from student's perspectives is also analysed. Recent research on the diversity for MOOCs learners has been done in analysing students varied motivations and interests on MOOCs. It is identified that yet MOOCs are often run and judged on the assumption that learners would progress through the course in its entirety, to completion. This research presents analysis of three recently delivered MOOCs that were designed to support a broader set of learner goals. A modular design was used, where each part included well defined learning outcomes and assessment criteria, and where completion was rewarded with digital badges. The paper proposes a new categorisation of learner achievement and methods of visualising learner behaviour that compliment this more open design. Results show that this approach recognises micro-learning that is missed if only completion rates are considered (Leach \& Hadi, 2017).

This paper presents a design MOOC course called Multimedia Systems and Applications (MSAC) MOOC. It provides students with essential knowledge on multimedia systems and applications based on interactive teaching and learning platform using open Learning. Students can apply the acquired knowledge in designing multimedia systems and applications such as text, graphics images, audio, video, animation which presented online on MOOC. The designed MOOC is different to attracts everybody in the world to participate online no matters which academic background they have. The designed MOOC then is analyzed and result based on student's participations, origins, assessment and feedback from the students is presented. Research is significant in identifying students' completion of the course understanding applied tools. The MOOC course is significant for today's teaching and learning strategy that need to be ready align with new technologies and development.

\section{LITERATURE REVIEW}

\subsection{MOOC as Teaching and Learning Platform}

Massive open online course (MOOCs) are transforming the era of distance learning education that has attracted a huge amount of attention from the media, education institutions, and education professionals. A 
study that measure the effectiveness of courses delivered using MOOCs in Taylor's University has been done (Goh, Wong, \& Ayub, 2018). A Kirkpatrick's four levels of evaluation learning model were adapted to measure the effectiveness of MOOCs. A descriptive survey of 250 learners was conducted and indicated that comprehensive study materials in MOOCs are useful for the learners as future reference. MOOCs are effective in the sense that it helps learners to understand a certain topic and apply it in real life. The program has met the learners' expectations and it is recommended the course to others. It is also identified that learners think that the study materials are sufficient for beginners, but advanced course is needed to meet their future job expectation. This study focuses on MOOCs in Open Learning platform and expanded to focus on different MOOC platforms besides in future. Since there is a deployment guide on how to start an institution-wide implementation of MOOC in higher learning institutions. A research on pedagogy framework detailing the strategies implemented throughout the university to kick start the MOOC project has been done. The pedagogy framework contains a plan on developing a sustaining momentum of academic's participation for MOOCs. This research reflects on the content development process which includes training the academicians for MOOC, highlighting the challenges faced by the e-Learning Academy (eLA) team and sharing best practices applied by lecturers in managing a MOOC and the way forward for MOOC in the context of a Malaysian private university (Ayub \& Leong, 2017).

In implementing MOOCs, a study is proposed to examine the dominant design and learning strategy used by various MOOCs platforms to foster students' Self-Directed Learning. Method used in the study was based on the search of relevant literature through online database such as IEEE Explore, ProQuest, ScienceDirect and ResearchGate. The keywords in the search for the relevant literature include MOOCs and learning strategy, MOOCs and design strategy, MOOCs and Self-Directed Learning. The result of the meta-analysis revealed that the most frequently used learning strategies by the various MOOCs platforms are the social constructive and peer-to-peer approach to learning. These two strategies are found to be related to cMOOCs and xMOOCs. This study concluded with provided a snapshot on design approach and learning strategies platform of learner's perspectives in MOOC. Typically, MOOC strategies platform applied learning strategies with four categories namely group based learning, blended learning, flipped classroom, and brain rewiring. These strategies involved basic steps as a guide to design an effective MOOC. Based on the results, group based learning was the most effective strategy to implement in MOOC. Most of the design approach of studies was focused on CMOOC. While the most common platform was Open Learning and Coursera (Mamman et al., 2017). Another study has described several significant conclusions regarding the understanding towards MOOC in the context of three selected Malaysia public university lecturers. The research also pinpointed the suggestion for MOOCs improvement as well as the suggestion for research and instrument development to improve the implementation of MOOC. At this early stage, it is acknowledged the introduction of $\mathrm{MOOC}$ as a positive innovation that can hopefully promise the transformation and modernisation of higher education. MOOC has a potential to have social advantages that they can attract and bring together like-minded Malaysians who have a vested interest in education and learning alighted with the fast-paced and technologically-driven environment of the 21st century (Ghazali \& Nordin, 2017).

\subsection{MOOC Platform Model}

Massive open online courses (MOOCs) provide people from all over the world and gives opportunity to expand their education for free without any commitment or prior requirements. Among the popular MOOC platform includes Coursera, edX, FutureLearn, OpenLearning, and Udemy. MOOC in education must have three requirements; (i) assessment (ii) instructor and (iii) model (Hashim, Salam, Mohamad, Mee, \& Ee, 2017), (Chatti, Muslim, \& Schroeder, 2017). Platform model for MOOC has been developed to achieve best blended and online learning using MOOC. Large-scale online open course (MOOC) is a new online learning model in the field of distance open education in recent years. It is embodies the learner as the centre of the teaching philosophy, changing the traditional network curriculum content fixed, structured features, so that learners access to knowledge from simple linear to complex networks. Framework of MOOC learning management system has been designed for example it is based on the existing Learning Technology Systems Architecture (LTSA) model to increase the interaction agent and knowledge agent two components (Liu, Gao, \& Li, 2017). The Learning Technology Systems Architecture (LTSA) is an abstract model describing the architecture of learning environments. It contains processes describe the main subsystems of learning processes. Knowledge of the learning resource database can be updated with the progress of the curriculum and Learners can build a learning network through different ways to obtain knowledge. Table 1 present some implemented MOOC design models that has been designed in MOOC courses and published in 2017. 
Table I: MOOC Design Model published in 2017

\begin{tabular}{|c|c|c|c|}
\hline & Models & Objectives & Achievement \\
\hline 1. & $\begin{array}{l}\text { Multi-level Analysis } \\
\text { (Poquet, Dawson, \& } \\
\text { Dowell, 2017) }\end{array}$ & $\begin{array}{l}\text { To establish potential indicators for } \\
\text { evaluating social activity in MOOCs, } \\
\text { particularly in relation to forum facilitation }\end{array}$ & $\begin{array}{l}\text { - Results demonstrated that } \\
\text { moderating the forum per se is } \\
\text { insufficient for the effective } \\
\text { evolution of participation. } \\
\text { - Courses with teaching } \\
\text { assistants and staff } \\
\text { demonstrate different patterns } \\
\text { than those with instructor } \\
\text { involvement. }\end{array}$ \\
\hline 2. & $\begin{array}{l}\text { Using fuzzy } \\
\text { comprehensive } \\
\text { evaluation method (Er- } \\
\text { Dong, Chao-Ran, \& Li- } \\
\text { Wei, 2017) }\end{array}$ & $\begin{array}{l}\text { - To ensure the quality of teaching and talent } \\
\text { training, and to promote the healthy } \\
\text { development of MOOC industry } \\
\text { - To establish a curriculum evaluation } \\
\text { system this matches the characteristics of } \\
\text { MOOC. }\end{array}$ & $\begin{array}{l}\text { Quality of MOOC courses } \\
\text { effectively }\end{array}$ \\
\hline 3. & $\begin{array}{l}\text { Using problem-oriented } \\
\text { project-based hybrid e- } \\
\text { learning approach (Din, } \\
2017 \text { ) }\end{array}$ & $\begin{array}{l}\text { - As the pedagogy to achieve what was } \\
\text { designed using UDL (universal design for } \\
\text { learning) to achieve meaningful learning. } \\
\text { To measure meaningful learning in new } \\
\text { design and implementations by assuring } \\
\text { learning occurs within the realm of active, } \\
\text { authentic, constructive, collaborative and } \\
\text { intentional learning. }\end{array}$ & $\begin{array}{l}\text { This note end with a brief } \\
\text { discussion about a learning design } \\
\text { within the development model } \\
\text { inspired by universal design for } \\
\text { learning model. }\end{array}$ \\
\hline 4. & $\begin{array}{l}\text { Incorporating } \\
\text { gamification component } \\
\text { in MOOC (Bakar, } \\
\text { Yusof, lahad, \& Ahmad, } \\
\text { 2017) }\end{array}$ & $\begin{array}{l}\text { - To engage students to be more active in } \\
\text { using MOOC. } \\
\text { - To develop a framework in order to } \\
\text { implement gamification in MOOC } \\
\text { effectively. }\end{array}$ & $\begin{array}{l}\text { Reviews of MOOC with } \\
\text { gamification globally to further } \\
\text { understand its effectiveness. }\end{array}$ \\
\hline 5. & $\begin{array}{l}\text { Video Engagement by } \\
\text { Gamification (Zhu, Pei, } \\
\text { \& Shang, 2017) }\end{array}$ & $\begin{array}{l}\text { - To achieve completion rate of MOOCs } \\
\text { - To get high engagement of learning in } \\
\text { MOOCs. }\end{array}$ & $\begin{array}{l}\text { Proposed a gamification design of } \\
\text { MOOC videos by adding implicit } \\
\text { feedback into mechanics and } \\
\text { updating existing delivery media } \\
\text { from lecture-style to narrative-style. }\end{array}$ \\
\hline
\end{tabular}

\subsection{Tools on MOOC}

Tools used in develop MOOC courses is one of the important component needed to develop MOOCs. Many tools such as software, web tools or authoring tools are used in MOOCs to design presentations that would invite students to participate, gave attractions and enjoy MOOCs. Some tools were used to make it more stylish, creative and better communications between students and lecturers such as tag of online Blogs and Forum (Mak, Williams, \& Mackness, 2010), add on presentable Videos (Alario-Hoyos, Pérez-Sanagustín, Delgado-Kloos, Muñoz-Organero, \& Rodríguez-de-las-Heras, 2013), link to web services and software architectures (Cruz-Benito, Borrás-Gené, García-Peñalvo, Blanco, \& Therón, 2015), insert with cloud based tools (Gütl, Rizzardini, Chang, \& Morales, 2014) and add on pedagogy tools (Calter, 2013) or designed with testing online tools (Pappano, 2012). Thus, this research presents a developed MOOC that used videos such as links to YouTube and online animation likes Powtoon to attract students watch it online in understanding this course related to Multimedia System and Applications. Others are Internet links to a few e-Learning systems which assessed students with quizzes are also inserted to this MOOC. The used of developed tools or authoring tools make it easier for marking according to assign topic in the course that maps to course outcomes and program outcomes for this course.

\section{METHODOLOGY}

The developed MSAC is based on set criterion that has been set by the e-learning department in the university.

\subsection{Landing Page Description}

Figure 1 shows the design of landing page for the MOOC course. Important elements such as Promo video is developed between 1 to 3 minutes as well as Introduction video. Course Synopsis is written on MOOC and 
detail explanations is described. List modules is presented and course learning outcome is listed which map in three Course outcomes to three program outcomes. Pre-requisite knowledge is stated which presents duration of the course. Progress of lectures and student's active in MOOC can be identified with badges and certificates achievement for each user. E-learning admin which has the control to monitor the quality of the designed MOOC is appointed and administrator of the course.

\subsection{Topic Description}

Details designed of each topic in the course are shown as in Figure 2. Eleven topics for this course are inserted online. Each topic presents topic learning outcome, minimum three main content, three activities, one assessment and two links related to multimedia systems and applications course. Sample of activities derived in MOOC are ice breaking questions, quizzes, Kahoot and short questions. Figure also shows the flow structure connected with content and activities.

\subsection{Massive Students}

Figure 3 shows seven (7) elements which has been design in the MOOC for multimedia systems and Applications Course. Course is designed to welcome massive students from all over the world online. Minimum target for the designed MOOCs is 500 students. Open course is set where open registration is scheduled, open content is setup, free of charge and affordable and welcome to all internet and online users. Online course is open where real time Interactions can be done between lecturers and students when they are online. Local Cohorts is configured as well as worldwide online students.

\section{ANALYSIS AND RESULT}

Analysis based on student's activities on the development MOOC is presented based on content and course achievement and student's activities.

\subsection{Content and Course Achievement}

Figure 4 shows content offered in the designed MOOC. Registered students to the MOOC are eligible to run all the three contents, three activities, links and assessment for the 11 derived topics for Multimedia System and Applications Course. Badges and certificates for completed students on the course can be achieved after students fulfil the whole course topics and activities. Figure 5 shows students' origin from their countries when they registered for the MOOC course. This course is not fully online since it is open in March 2017 but some worldwide students are interested on the MOOC course which presents 269 students from Malaysia and each one registered student from Spain and United States. This shows some interested value from World Wide Web users on the developed MOOC. Figure 6 shows lecturers activities that present how active they were in the MOOC course. Kudos presents the student's admiration that lecturer receives as a result of a particular achievement such as how actives they were in replying messages or comment in MOOC. The new developed MOOC presents some lecturers who have received Kudos as highest at 160 point and lowest is 3 point. Although it is new MOOC course but the lecturers presents how actives they were in the MOOC. 


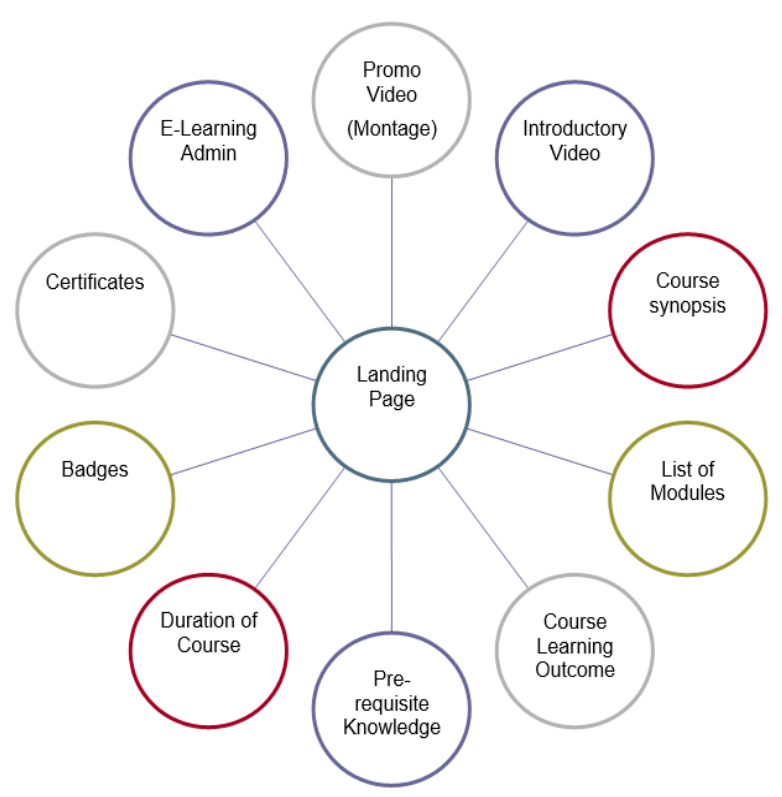

Fig. 1. Design of Landing Page

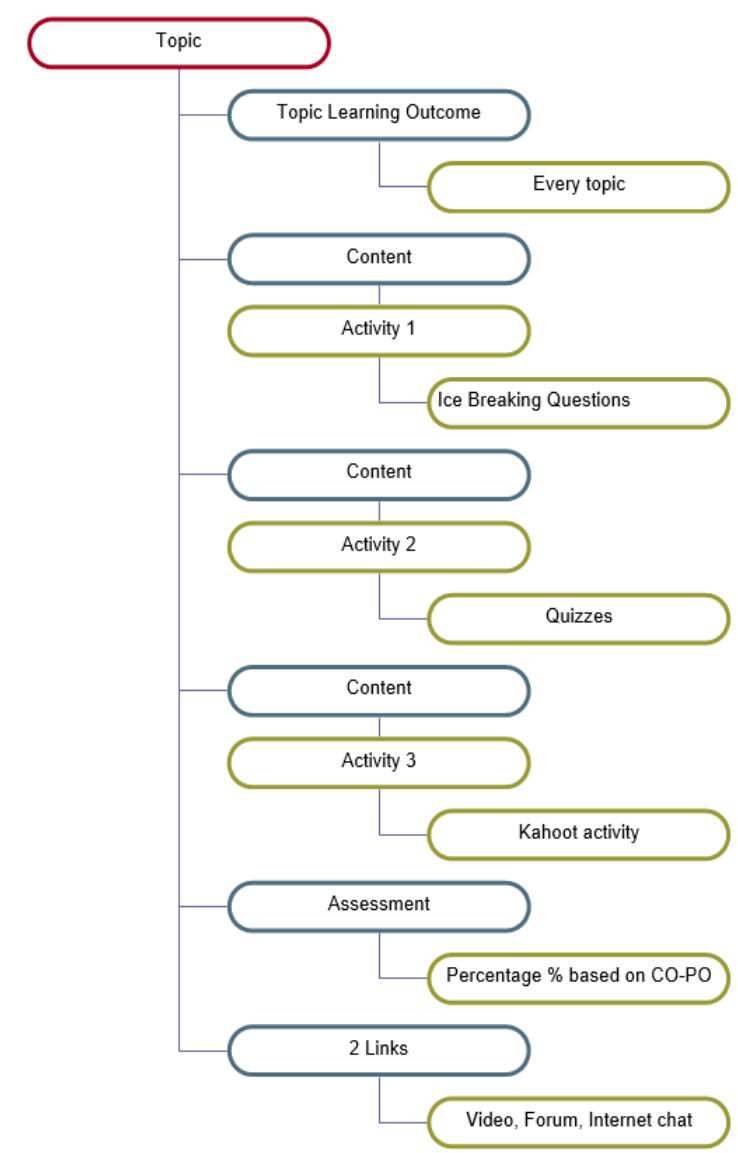

Fig. 2. Design Structure of Topic in MOOC

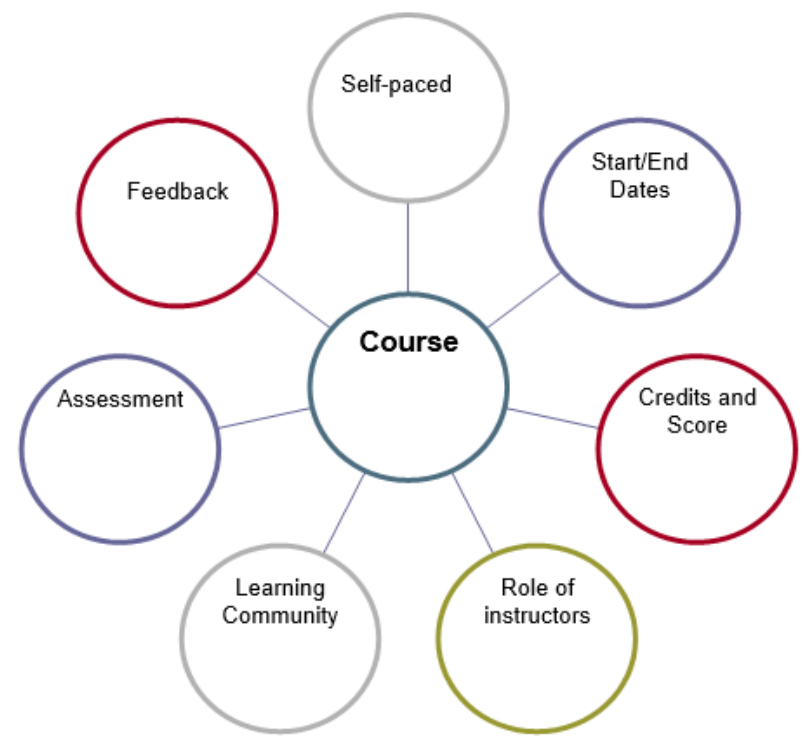

Fig. 3 Seven Elements Designed MOOC Course 


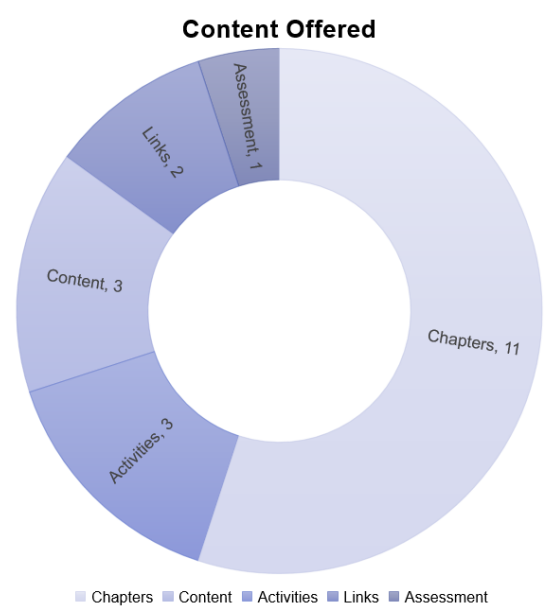

Fig 4. Design content and activities

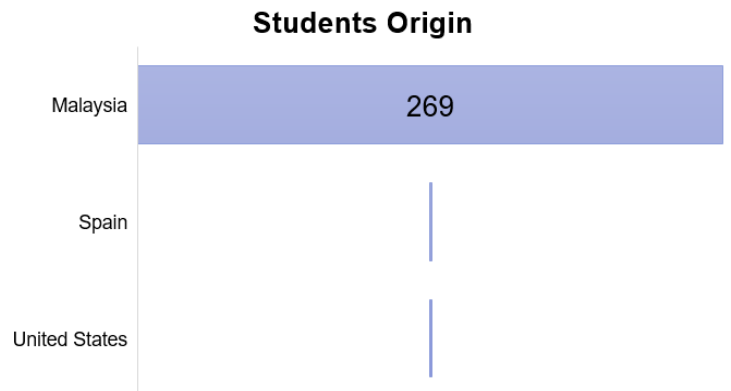

Fig. 5 Student's Origin

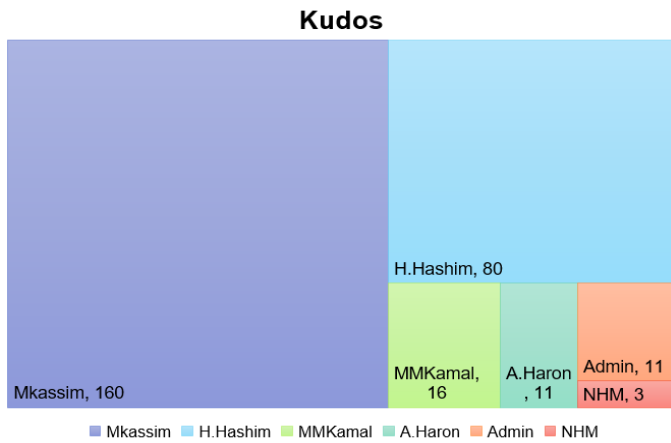

Fig. 6. Achieved Kudos

\subsection{Student' Activity}

Analysis on student's activities is automatic recorded in MOOC while they are registered for the course.

\subsubsection{Students' Progress}

Figure 7 shows total students in MOOC are 263 students which present 4220 comments on the last 4 days students' visits to the MOOC course. The developed MOOC course is new and on a tested period. Some students are allowed to register on the online MOOC for testing purposes and they are not necessary to finish on the trial runs. This is because their actual class has started earlier while this MOOC is in development progress. Thus, graph presents only three administrators finish the progress and others are still in progress. Total developed pages are 27 pages for this MOOC course.

\subsubsection{Daily Active Students}

Figure 8 shows daily active students in MOOC course from March to August 2017 that presents maximum active students is 95 between in the month of March to April and the lowest is between July to August 2017.

\subsubsection{Student's Interactive over Time}

Figure 9 shows student's Interactive over time that presents their daily comments and likes to reply and activities in MOOC. Two elements of students interactive over time are measured with their comments and likes in MOOCs. It is identified the maximum comments is 1,800 and 950 likes which is between April to May 2017. 
Open Class of 2017 (263 students, 4220 comments, last active 4 days ago)

Lis pages

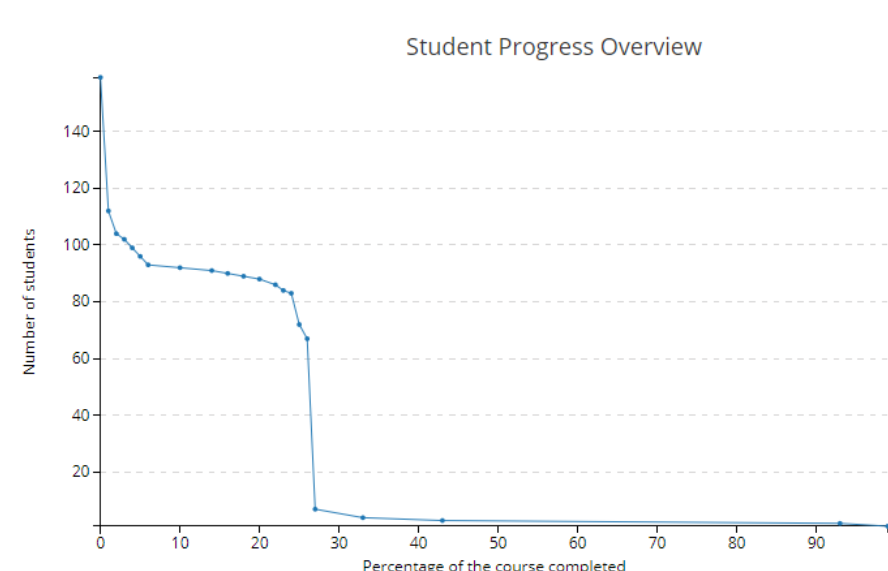

Fig. 7. Student's Progress Overviews

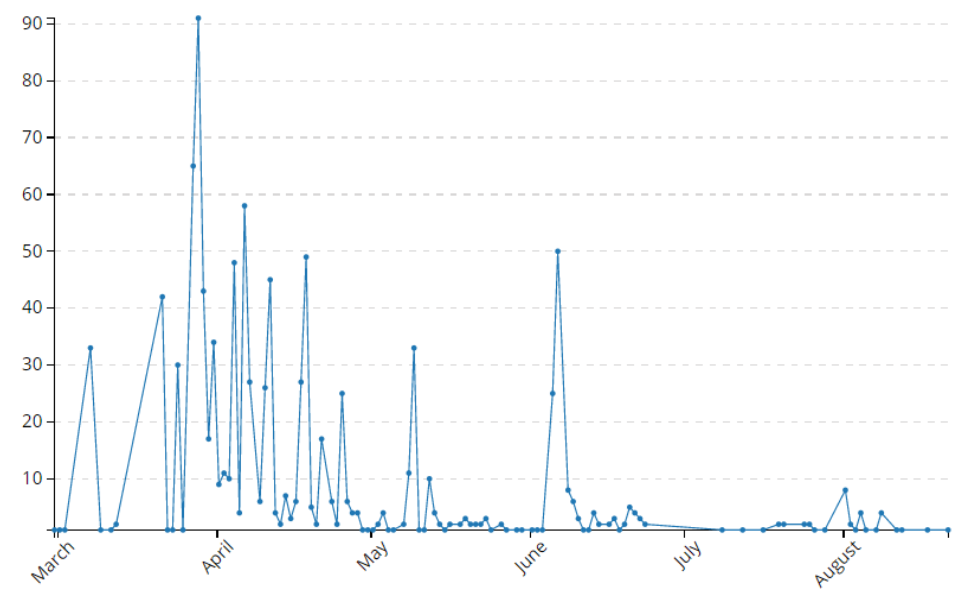

Fig. 8 Daily Active Students

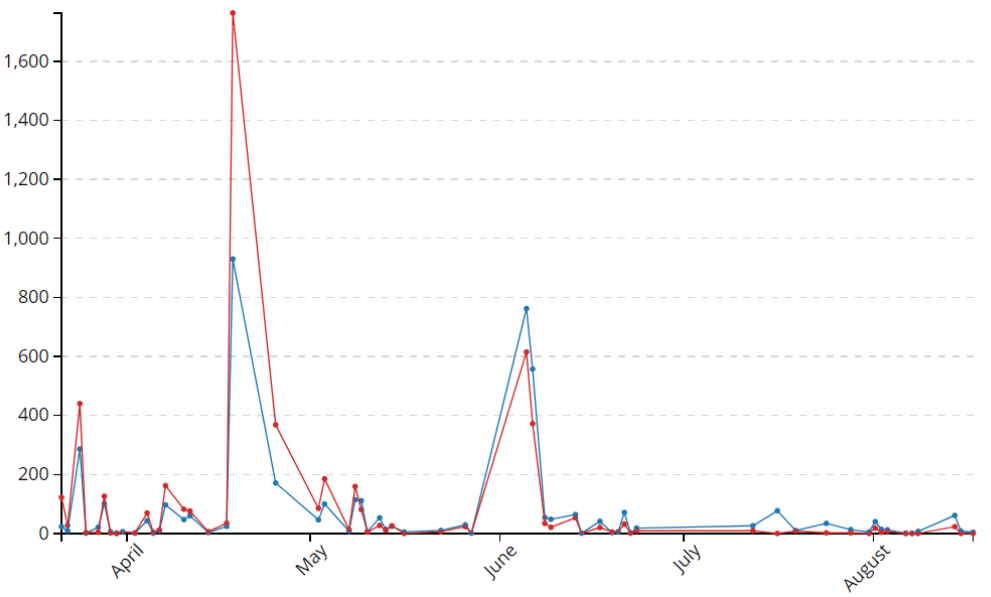

Fig. 9 Student's Comment and Likes
Students

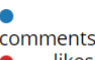

likes

\section{CONCLUSION}

This research presents a development of MOOC course on Multimedia Systems and Development course which is on trial running period started on March 2017. The MOOC is presented online while at the same 
time development topics and module on MOOC is in progress. At the same time, students are allowed to join the $\mathrm{MOOC}$ as testing presentations on teaching and learning progress for non-face to face activities for this course. Analysis present quite a high number of students join the MOOC and impressive comments and likes are gathered from the open learning platform. Students are able to communicate online and some questions are response through online answers either submitted direct on the platform or file submitted. Results present the design $\mathrm{MOOC}$ is completed according to design structure approved by the university e-learning centre. Analysis results shows $50 \%$ students registered from the needed target which is 500 students. Students' progress present they are active in the MOOC course which presents history of maximum 95 students active in a day. Comment and likes reply from students shows 1,800 and 950 response in a day that presents how active of students runs in the MOOC course. This research is significant in identifying how MOOCs can help students in understanding the course through online learning. This MOOC are internetbased courses that implemented with free of charge which caters large numbers of students. In a typical MOOC has specific start and end dates, a more-or-less defined topic of study, facilitators with video, notes and animations. Assessments are set according to topics which are easier to monitor. Students are able to watch short video lectures online and complete the assignments that are graded either automatically or by peers from the developed MOOC. Future research could be done, where analysis on students spending time on MOOCs and their achievement on the given assessment by topics. Details data on their active time, progress, kudos and number of comments can be analysed and evaluations on students' performance can be retrieved based on non-face to face activities in learning Multimedia Systems and Application course using MOOC open learning platform.

\section{ACKNOWLEDGMENT}

Authors would like to thank Universiti Teknologi MARA and Ministry of Higher Education (MOHE) for the support grant ARAS number 600-RMI/DANA 5/3/ARAS (27/2015) for this research.

\section{REFERENCE LIST}

Ab Rahman, R., Ahmad, N., Kassim, M., Ku Haroswati, C., \& Ku Yahaya, C. (2009). Case study of a smart collaboration: FEE-UiTM \&amp; Cisco Network Academy experience. [Article]. 2009 International Conference on Engineering Education, ICEED2009 - Embracing New Challenges in Engineering Education, 92-96. doi: 10.1109/iceed.2009.5490605

Alario-Hoyos, C., Pérez-Sanagustín, M., Delgado-Kloos, C., Muñoz-Organero, M., \& Rodríguez-de-lasHeras, A. (2013). Analysing the impact of built-in and external social tools in a MOOC on educational technologies. Paper presented at the European Conference on Technology Enhanced Learning.

Arnott, J. A., \& Planey, S. L. (2017). Flipped classroom approaches lead to no improvement in learning outcomes or student perceptions. The FASEB Journal, 31(1 Supplement), 751.714-751.714.

Ayub, E., \& Leong, L. C. (2017). Developing a Pedagogy Framework for Institution-Wide Implementation of MOOC: A Case Study from a Malaysian Private University. Advanced Science Letters, 23(2), 809813.

Bakar, N. F. A., Yusof, A. F., lahad, N. A., \& Ahmad, N. (2017). Framework for embedding gamification in Massive Open Online Course (MOOC). Paper presented at the Research and Innovation in Information Systems (ICRIIS), 2017 International Conference on.

Calter, M. (2013). MOOCs and the library: Engaging with evolving pedagogy.

Chatti, M. A., Muslim, A., \& Schroeder, U. (2017). Toward an Open Learning Analytics Ecosystem Big Data and Learning Analytics in Higher Education (pp. 195-219): Springer.

Cruz-Benito, J., Borrás-Gené, O., García-Peñalvo, F. J., Blanco, Á. F., \& Therón, R. (2015). Extending $M O O C$ ecosystems using web services and software architectures. Paper presented the Proceedings of the XVI international conference on Human Computer Interaction.

Din, R. (2017). Notes from the Chief Editor On Designing Personalized Learning. Journal of Personalized Learning, 2(1).

Er-Dong, Z., Chao-Ran, G., \& Li-Wei, L. (2017). The Construction of MOOC's Curriculum Evaluation System Model in China. DEStech Transactions on Social Science, Education and Human Science(mess).

Ghazali, N. B., \& Nordin, M. S. (2017). The Perception of University Lecturers of Teaching and Learning In 
IJAEDU- International E-Journal of Advances in Education, Vol. III, Issue 9, December 2017

Massive Open Online Courses (MOOCs). Journal of Personalized Learning, 2(1), 52-57.

Goh, W. W., Wong, S. Y., \& Ayub, E. (2018). The Effectiveness of MOOC Among Learners Based on Kirkpatrick's Model Redesigning Learning for Greater Social Impact (pp. 313-323): Springer.

Gütl, C., Rizzardini, R. H., Chang, V., \& Morales, M. (2014). Attrition in MOOC: Lessons learned from dropout students. Paper presented at the International Workshop on Learning Technology for Education in Cloud.

Hashim, H., Salam, S., Mohamad, S., Mee, C., \& Ee, T. (2017). Analysis of student performance using massive open online courses as blended learning approach in learning second language. Proceedings of Mechanical Engineering Research Day 2017, 2017, 296-298.

Kassim, M., Kamal, M. M., Sani, M. M., \& Johari, J. (2015, 17-18 Nov. 2015). Self-learning website development through online internet knowledge among engineering students. Paper presented at the 2015 IEEE 7th International Conference on Engineering Education (ICEED).

Leach, M., \& Hadi, S. M. (2017). Supporting, categorising and visualising diverse learner behaviour on MOOCs with modular design and micro-learning. Journal of Computing in Higher Education, 29(1), 147-159.

Liu, S., Gao, T., \& Li, T. (2017). Design and Implementation of Large-Scale MOOC Platform in Colleges and Universities. International Journal of Advanced Pervasive and Ubiquitous Computing (IJAPUC), 9(1), 57-63.

Mak, S., Williams, R., \& Mackness, J. (2010). Blogs and forums as communication and learning tools in a MOOC. Paper presented at the Proceedings of the 7th International Conference on Networked Learning 2010.

Mamman, B., Yusof, A., AbuHassna, H. M., Aly, H., Al-Ahmadi, T., Atan, N. A., . . Yahaya, N. (2017). Design and Learning Strategies Applied in Mooc: A Meta-Analysis. Sains Humanika, 9(1-4).

Murugesan, R., Nobes, A., \& Wild, J. (2017). A MOOC approach for training researchers in developing countries. Open Praxis, 9(1), 45.

Pappano, L. (2012). The Year of the MOOC. The New York Times, 2(12), 2012.

Pérez-Sanagustín, M., Hilliger, I., Alario-Hoyos, C., Kloos, C. D., \& Rayyan, S. (2017). H-MOOC framework: reusing MOOCs for hybrid education. Journal of Computing in Higher Education, 29(1), 47-64.

Poquet, O., Dawson, S., \& Dowell, N. (2017). How effective is your facilitation?: group-level analytics of MOOC forums. Paper presented at the Proceedings of the Seventh International Learning Analytics \& Knowledge Conference.

Rahman, R. A., Zan, M. M. M., Abidin, H. Z., Kassim, M., \& Yahaya, C. K. H. C. K. (2010, 6-9 April 2010). Impact of Globalization and Industry on Engineering Education at Higher Learning Education in Malaysia. Paper presented at the 2010 IEEE Transforming Engineering Education: Creating Interdisciplinary Skills for Complex Global Environments.

Wahid, A., Ibrahim, A., \& Hashim, N. B. (2017). THE REVIEW OF TEACHING AND LEARNING ON ENTREPRENEURSHIP EDUCATION IN INSTITUTION OF HIGHER LEARNING. Journal on Technical and Vocational Education, 1(2), 82-88.

Zhu, Y., Pei, L., \& Shang, J. (2017). Improving Video Engagement by Gamification: A Proposed Design of MOOC Videos. Paper presented at the International Conference on Blended Learning. 